\title{
Trend of Human Vibration Research in Korea
}

\author{
Hee-Sok Park
}

Department of Industrial Engineering, Hongik University, Seoul, 121-791

\begin{abstract}
Objective: The objective of this study is to examine the characteristics of the research on human vibration in Korea. Background: There have been relatively less interests in vibration than other ergonomic factors in Korea. However, the importance of vibration is increasing as industry and everyday life are more mechanized. Method: This study reports the results of the literature review on the papers about human vibration published in ergonomics-related domestic journals. Results: It was found that more studies have been done on local vibration than on whole body vibration. Diverse topics have been studied in ergonomics community. Conclusion: Further cutting-edge studies are expected than classical safety and health related ones. Application: Some suggestions were proposed hopefully helpful to colleague ergonomists for future research.
\end{abstract}

Keywords: Human vibration, Review, Research trend, Korea

\section{Introduction}

산업과 일상생활의 기계화와 더불어 진동이 인체에 미치 는 영향은 점점 커지고 있다. 자동차나 배 같은 운송수단에 타고 있는 경우, 진동이 발생하는 건축물에 거주하는 경우, 그리고 착암기 등 진동장비를 사용하는 작업환경 등이 우리 몸을 생리적 또는 심리적으로 불편하게 한다. 이에 따라 업 무수행 능력이 저하되고 질병이 유발되기도 한다.

여러 선진국과 국제기관에서는 진동의 부정적인 영향을 예방 및 관리하기 위하여 오래 전부터 많은 노력을 경주하여 왔으나, 우리나라에서는 다른 작업관련 요인에 비하여 진동 에의 관심이 상대적으로 적은 실정이다.

이에 본 논문에서는 우리나라의 인간공학 연구자들이 주 로 참조하는 대표적인 국내학술지에 게재된 진동관련 논문 의 특성을 분석하여, 인체진동 관련 연구의 동향을 고찰하 고자 한다. 본 논문이 인간공학 연구자들의 진동에의 관심을 증대시켜 관련 연구의 수준을 제고하는데 기여하기를 기대 한다.

\section{Method}

국내외적으로 인체진동 관련 논문은 다양한 학술지에 게 재되고 있으며, 여기에서는 우리나라 인간공학 연구자들과 밀접한 관련이 있는 대한인간공학회(Ergonomics Society of Korea: ESK), 대한산업공학회(Korean Institute of Industrial Engineers), 한국감성과학회(Korean Society of Emotion and Sensibility: KSES), 한국산업위생학회 (Korean Industrial Hygiene Association: KIHA), 대한 직업환경의학회(Korean Society of Occupational and Environmental Medicine: KSOEM) 에서 발간되는 정기학 술지를 분석대상으로 하였다. 한국소음진동공학회지, 대한기 계공학회지에도 인체진동 관련 논문들이 많이 발표되고 있 지만 그 내용과 접근방법이 인간공학과 사뭇 다르므로 분석 에서 제외하였다.

학술대회 발표논문은 엄격한 심사과정 (peer review)을 거 치지 않는 우리나라의 사정을 고려하여 분석대상에서 제외 하였다. 논문의 검색은 $\mathrm{DBPia}, \mathrm{KISTI}, \mathrm{KISS}$ 등의 데이터

Corresponding Author: Hee-Sok Park. Department of Industrial Engineering, Hongik University, Seoul, 121-791.

Phone: +82-2-320-1473, E-mail: hspark@hongik.ac.kr

Copyright@2013 by Ergonomics Society of Korea(pISSN:1229-1684 eISSN:2093-8462). All right reserved.

(c) This is an open-access article distributed under the terms of the Creative Commons Attribution Non-Commercial License(http://creativecommons.org/licenses/by-nc/3.0/), which permits unrestricted non-commercial use, distribution, and reproduction in any medium, provided the original work is properly cited. http://www.esk.or.kr 
베이스를 이용하였으며, 1990년 이후에 게재된 논문들을 대 상으로 하였다.

\section{Results}

인체진동은 전달되는 범위에 따라 전신진동 (whole body vibration: $\mathrm{WBV}$ )과 손과 팔 등 신체 일부에 전달되는 국소 진동 (local vibration: LV)으로 나누어진다. Table 1에 각 학술지 별 전신진동과 국소진동의 연구비중을 나타내었다.

Table 1. Classification of the papers into WBV and LV

\begin{tabular}{l|c|c|c|c}
\hline & WBV & LV & Both & Total \\
\hline ESK & 1 & 8 & 1 & 10 \\
\hline KIIE & 0 & 2 & 0 & 2 \\
\hline KSES & 0 & 1 & 0 & 1 \\
\hline KIHA & 2 & 4 & 0 & 6 \\
\hline KSOEM & 1 & 14 & 0 & 15 \\
\hline Total & 4 & 29 & 1 & 34 \\
\hline
\end{tabular}

ESK: Ergonomics Society of Korea, KIIE: Korean Institute of Industrial Engineers, KSES: Korean Society of Emotion and Sensibility, KIHA: Korean Industrial Hygiene Association, KSOEM: Korean Society of Occupational and Environmental Medicine

\subsection{Whole body vibration}

Table 1에서 보듯이 전신진동 관련 논문의 수가 국소진동 에 비하여 현격하게 적었다. 대한인간공학회에서는 앉아있는 선박 승무원에게 전달되는 진동파의 수학적 모델링 (Kim et al., 2003)이 발표되었고, 한국산업위생학회는 굴삭기의 진 동 특성을 측정한 연구(Choi et al., 2002)를 들 수 있다. 대한직업환경의학회에서는 장기간의 진동작업과 부적절한 자세 하에서 요통이 발생한 사례가 보고되었다(Jeong and Roh, 2009).

\subsection{Local vibration}

대한인간공학회에는 진동증후군과 관련된 연구(Park and Yim, 2000; Yim et al., 2002), 그라인딩 작업 시의 다양한 손목자세와 진동전달 특성에 관한 연구(Hwang et al., 2007), 드릴의 적정 무게에 관한 연구(Lee and Kim, 2000), 진동 환경 하의 근육피로에 관한 연구(Lee and Kim, 1999) 등
수공구 사용과 관련한 논문들이 많이 발표되었다. 그 외 진 동촉각의 민감도에 관한 연구(Lee, 1998; Lee, 1999)와 진동관련 표준과 측정방법에 대한 기술논문이 게재되었다 (Park and Jang, 1999; Park, 2011).

대한산업공학회에는 휴대폰 진동의 적정 주파수에 관한 연구(Lee et al., 2004)와 자동차 조립라인의 수공구 진동의 측정결과가 보고되었다(Park and Huh, 2004).

한국감성과학회에는 진동센서를 이용하여 코골이 방지 베 개를 개발한 사례(Jee et al., 2011)가 발표되었다.

한국산업위생학회에서는 방진 장갑에 관한 연구(Choi et al., 2008)와 진동공구를 사용할 때의 진동특성을 측정 및 평가한 논문 3편이 발표되었다.

대한직업환경의학회는 전공분야의 특성 상, 진동증후군의 의학적 평가(Yoon et al., 2012) 와 진단 및 검사방법(Yoon et al., 2009)으로 연구분야를 대별할 수 있다.

\section{Conclusion}

본 논문에서 비록 일부이기는 하나 우리나라 인간공학 연 구자들의 인체진동 관련 연구동향을 고찰하였다.

첫째, 전신진동보다는 국소진동에 대하여 많은 연구가 수 행되었음을 알 수 있었다. ISO에서는 전신진동의 영향으로 서 (척추)건강, 안락함(comfort), 지각(perception) 능력, 멀미 등 4 개 영역으로 구분하고 있다(ISO, 1997). 현재 우 리나라에서는 주로 전신진동이 건강에 미치는 영향에 관심 이 있으며, 추후 업무수행 능력에 미치는 영향에 대한 관심 이 요구된다.

둘째, 인체진동의 전통적인 응용분야인 안전보건에서 진일 보하여 다양한 주제에 관한 연구가 기대된다. 예를 들어, 진 동은 정보전달 매체로서 많은 역할을 할 수 있으며(예: 휴대 폰 진동, 장애우를 위한 신호 등), 불편함의 대상이 아니라 쾌적함과 안락감을 줄 수 있는 대상이 될 수 있으므로 이에 대한 연구가 필요하다.

셋째, 진동에 의한 여러 영향의 예방과 관리에 관한 우리 나라 표준이 필요하다. 현재까지는 주로 국제적인 표준을 원 용하여 왔으나, 우리나라 사람들과 작업환경에 적합한 표준 을 개발하는 국가적인 연구가 필요하다.

본 논문은 진동관련 학술지 모두를 분석하지 못한 한계점 이 있다. 즉, 한국소음진동공학회지, 대한기계공학회지에도 인체진동 관련 논문들이 많이 발표되고 있지만 그 관심과 접근방법이 인간공학과 다르기 때문에 분석에서 제외하였다.

본 특집호에 인체진동의 여러 측면에 대하여 국내 대표적 인 연구자들의 연구결과를 집약하였다. 본 특집호가 인체진 
동 연구의 발전에 기여하기를 바란다.

\section{Acknowledgements}

This work was supported by 2012 Hongik University Research Fund.

\section{References}

Kim, H.S., Kim, H.T. and Park, J.H., A study of mathematical human modeling of sitting crew during whole-body vibration, Journal of Ergonomics Society of Korea, 22(1), 1-15, 2003.

Choi, H.D., Kim, H.W, Sung, J.H., Choi, J.W. and Yang, H.S., Exposure assessment and factor analysis of whole body vibration of excavator workers, Journal of Korean Society of Occupational and Environmental Hygiene, 12(3), 202-210, 2002.

Choi, S.H., Hong, S.I. and Jang, H.K., Assessment of anti-vibration gloves for reduction of hand-transmitted vibration exposure, Journal of Korean Society of Occupational and Environmental Hygiene, 18(1), $1-10,2008$.

Hwang, S.H. and Lee, D.C., An analysis of transmitted vibration characteristics by different wrist posture during grinding tasks, Journal of Ergonomics Society of Korea, 26(1), 29-37, 2007.

ISO, ISO 2631-1 Mechanical vibration and shock - Evaluation of human exposure to whole-body vibration - Part 1: General requirements, Geneva, 1997.

Jeong, J.D. and Roh, S.C., Cervical HIVD related to long-term whole body vibration and awkward posture, Korean Journal of Occupational and Environmental Medicine, 21(4), 396-405, 2009.

Jee, D.K, Wei, R., Kim, H.S. and Im, J.J., Snoring detection using polyvinylidene fluoride vibration sensors, Korean Journal of the Science of Emotion and Sensibility, 14(3), 459-466, 2011.

Lee, B.W., Park, H.H. and Myung, R.H., JND-based mobile phone optimal vibration frequency, Journal of the Korean Institute of Industrial Engineers, 30(1), 27-35, 2004.

Lee, D.C. and Kim, G.J., The effects of hand-arm vibration on flexor and extensor fatigue, Journal of Ergonomics Society of Korea, 18(1), 55 $-69,1999$.

Lee, D.C. and Kim, G.J., Determination of recommendable powered drill weight by the characteristics of transmitted vibration on hand-arm system, Journal of Ergonomics Society of Korea, 19(2), 75-86, 2000.

Lee, S.I., Human sensitivity responses to vibrotactile stimulation on the hand: measurement of absolute thresholds, Journal of Ergonomics Society of Korea, 17(2), 1-10, 1998.
Lee, S.I., Human sensitivity responses to vibrotactile stimulation on the hand: measurement of differential thresholds, Journal of Ergonomics Society of Korea, 18(3), 1-12, 1999.

Park, H.S., Introduction of directive 2002/44/EC, Journal of Ergonomics Society of Korea, 30(2), 375-379, 2011.

Park, H.S and Huh, S.M., A Study on measurement and analysis of local vibration induced by the powered hand tools used in automobile assembly lines, IE interfaces, 17(3), 375-383, 2004.

Park, H.S. and Jang, D.S, Measurement and analysis of human vibration, Journal of Ergonomics Society of Korea, 18(3), 179-186, 1999.

Park, H.S. and Yim, S.H., An investigation of the symptom prevalence of hand-arm vibration syndrome among the workers using powered hand tools, Journal of the Ergonomics Society of Korea, 19(3), 93 $-107,2000$.

Yim, S.H., Park, H.S. and Yang, J.I., A study on the assessment of vibration produced by the powered hand tools used and hand-arm vibration syndrome prevalent in the shipbuilding industry, Journal of the Ergonomics Society of Korea, 21(4), 25-45, 2002.

Yoon, J.K, Lee, H, Choy, N.R., Kim, S.H., Park, H.O., Lee, J.H. and Yoo, C.I., Early objectified detection method of sensorineural component in hand arm vibration syndrome, Korean Journal of Occupational and Environmental Medicine, 21(2), 143-153, 2009.

Yoon, J.K, Sim, C.S., Oh, M.S., Sung, J.H., Lee, J.H., Lee, C.R., Kim, Y.H., Yoo, C.I. and Lee, H., The general characteristics and results of the cold provocation test in the risk group of HAVS, Korean Journal of Occupational and Environmental Medicine, 24(3), 207-216, 2012.

\section{Author listings}

Hee-Sok Park: hspark@hongik.ac.kr

Highest degree: $\mathrm{PhD}$, Department of Industrial and Operations Engineering, The University of Michigan

Position title: Professor, Department of Industrial Engineering, Hongik University

Areas of interest: Occupational ergonomics, Musculoskeletal disorders

Date Received : 2013-07-13

Date Revised :2013-07-31

Date Accepted : 2013-07-31 